\title{
Рентгеновские исследования образцов микрокристаллического кремния для панелей солнечных элементов
}

\author{
М.Д. Шарков, М.Е. Бойко, А.В. Бобыль, А.М. Бойко, С.Г. Конников \\ Физико-технический институт им. А.Ф.Иоффе, Санкт-Петербург, \\ 194021, Политехническая, 26 \\ тел:+7 (812) 292-7985, факс:+7 (812)297-1017, эл.nочта: mischar@mail.ru
}

DOI 10.34077/RCSP2019-68

Методом малоуглового рассеяния рентгеновских лучей (МУРР) исследованы два набора образцов микрокристаллического кремния ( $\mu \mathrm{c}-\mathrm{Si})$, произведенного для дальнейшего использования в качестве рабочего материала панелей солнечных элементов. Технология производства предполагала, что в каждом из наборов образцов зерна микрокристаллического кремния должны иметь размер 200 и 20 нм вдоль нормали к поверхности соответственно.

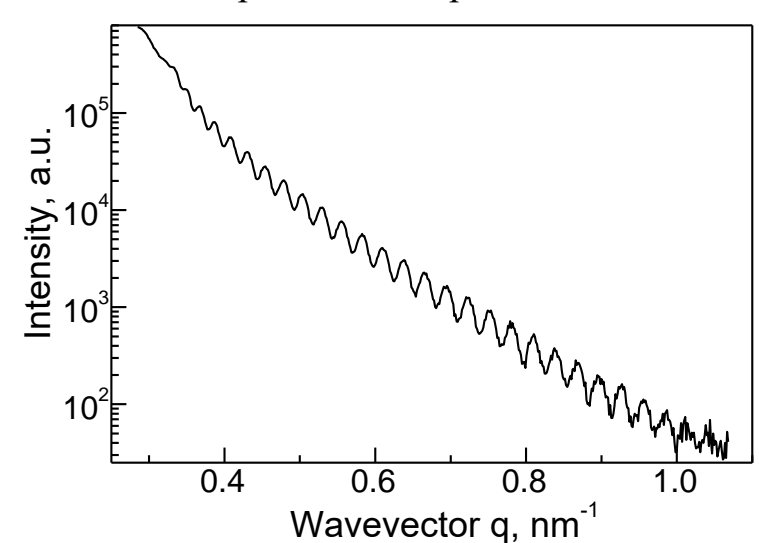

Рис. 1. Кривая МУРР от образца $\mu \mathrm{c}-\mathrm{Si}$, выращенного по технологии, ориентированной на зерна высотой 200 нм.

Кривые МУРР от всех образцов были зарегистрированы на установке ДРОН-8 в НПО «Буревестник» (СПб, Россия) в режиме отражения на $\mathrm{Cu} \mathrm{K} \mathrm{K}_{\alpha 1}$ излучении. Один из образцов был дополнительно подвергнут полировке поверхности, после чего от него были повторно получены данные МУРР как в режиме отражения, так и в просвечивающем режиме.

Результаты:

Показано, что в серии образцов, технология производства которых нацелена на зерна высоты 200 нм, реальные размеры зерен составляют от 205 до 240 нм. Продемонстрировано, как для одного из образцов (по кривой МУРР, приведенной на Рис. 1) определяется высота зерен $226 \pm 3$ нм.

Показано, что в серии образцов, технология производства которых нацелена на зерна высоты 20 нм, реальные размеры зерен составляют от 20 до 24 нм. Продемонстрировано, как для одного из образцов определяется высота зерен $22.9 \pm 0.1$ нм.

Показано, что в отполированном образце кривые МУРР показывают присутствие низкоразмерных компонент, а поверхность образца покрыта локально упорядоченной сетью зерен Si размером около 3 нм. 